\title{
Biomphalaria spp. (Preston, 1910) snails in the municipality of Juiz de Fora, Zona da Mata Mineira mesoregion, ate of Minas Gerais, Brazil
}

\author{
Sandra Helena Cerrato Tibiriçá/ ${ }^{+}$, Elisabeth Cristina Almeida Bessa, \\ Adalberto Mittherofhe*, Milton Ferreira de Castro*, Omar dos Santos Carvalho**, \\ Roberta Lima Caldeira**, Liana Konovaloff Jannotti Passos**, \\ Ana Márcia Menezes de Mattos***, Liliane Sena Pinheiro***, \\ Dirany Sacramento e Silva***, Fabiana Oliveira Bastos***, Gabriela Quirino Andreoli***, \\ Glauco Resende Bonato***, Elaine Soares Coimbra***
}

Pós-graduação em Comportamento e Biologia Animal ***Departamento de Parasitologia, Microbiologia e Imunologia, Instituto de Ciências Biológicas, Universidade Federal de Juiz de Fora, Campus Universitário, 36036-900 Juiz de Fora, MG, Brasil

*Diretoria de Ações Descentralizadas da Saúde/Juiz de Fora, Secretaria de Saúde do Estado de Minas Gerais,

Belo Horizonte, MG, Brasil **Laboratório de Helmintoses Intestinais, Centro de Pesquisas René-Rachou-Fiocruz, Belo Horizonte, MG, Brasil

This study focuses on the geographic distribution of the snail of the genus Biomphalaria and evaluates its infectivity by Schistosoma mansoni in 5264 specimens collected in the municipality of Juiz de Fora, Minas Gerais, Brazil. Of the 31 locations studied, 6 were reservoirs, 11 rudimentary holding ponds, 7 irrigation ditches, 5 lakes, 1 ornamental pond, and 1 waterfall. Intermediate hosts were found only in the rudimentary ponds and ditches, which were 100\% positive. Using morphological and molecular analysis techniques, B. tenagophila, B. peregrina, and B. straminea were identified. This is the first report of $\mathrm{B}$. stramínea in the municipality, and evaluation of its infective potential revealed susceptibility of $25.4 \%$. Although we did not find specimens of Biomphalaria infected by S. mansoni, the data obtained indicate the presence of intermediate hosts, especially in the irrigation ditches in Juiz de Fora, and their proximity to contaminated areas.

Key words: Biomphalaria - Biomphalaria straminea - schistosomiasis - geographic distribution - Juiz de Fora - Brazil

Schistosomiasis, an infection caused by Schistosoma mansoni, is one of the world's leading parasite-borne diseases, affecting 84 million people annually, in many developing countries (WHO 1998). In Brazil, where it is endemic, it affects about of 6 million people a year and figures among the country's most relevant infectious diseases, principally for its high morbidity/mortality index and wide geographic distribution (Schall \& Diniz 2001). It is distributed in four states of the Southeast Region. In the state of Minas Gerais, the endemic areas are located in the mesoregions of Norte de Minas, Campo das Vertentes, Oeste de Minas, Vale do Jequitinhonha, Vale do Mucuri, Vale do Rio Doce, Região Metropolitana de Belo Horizonte, Zona da Mata, and Central Mineira (Carvalho et al. 1997, Souza et al. 2001). A mesoregion is a group of microregions. A microregion is a set of contiguous municipalities in a single state, grouped according to a combination of geographic, economic and administrative characteristics.

Molecular evidence, corroborated by fossil findings, supports the hypothesis that snails of the genus Biomphalaria, an intermediate host of S. mansoni, originally

\footnotetext{
${ }^{+}$Corresponding author: tibi@interfire.com.br Received 25 May 2006 Accepted 26 June 2006
}

evolved in the Americas. Biogeographic studies indicate that an ancestor of B. glabrata from the New World dispersed in the Pliocene-Pleistocene (Campbell et al. 2000, DeJong et al. 2001), probably by rafting on vegetation or by eggs carried by migratory birds, crossing the Atlantic to Africa and giving rise to the current African species (Lockyer et al. 2004).

Among the 10 species of Biomphalaria found in Brazil, 7 have been identified in the state of Minas Gerais (Souza et al. 2001), including those susceptible to infection in nature: B. glabrata (Say 1818) B. tenagophila (Orbigny 1835), and B. straminea (Dunker 1848).

Of the state's 853 municipalities distributed in the 12 political-administrative mesoregions, 283 have been studied for the snail's prevalence. B. glabrata has been reported in $65.3 \%$ of the municipalities studied; $B$. straminea in $43.8 \%$; B. tenaghophila in $20.4 \%$; B. peregrina in $20.1 \%$; B. schrammi in $9.2 \%$; B. intermedia in $7 \%$, and $B$. occidentalis in $0.7 \%$ (Souza et al. 2001). The municipality in Brazil is the local political-administrative division, corresponding roughly to a county or prefecture. It is governed by a mayor and municipal council. Some municipalities are almost completely urbanized, others almost totally rural, and some, like Juiz de Fora, a mixture of the two.

The most recent scientific report on the occurrence of Biomphalaria in Juiz de Fora municipality, the main social and economic center in the state's Zona da Mata 
Mineira, dates from 1956 (Paraense \& Deslandes) and hence contains information from 50 years ago on the location of the species found. Recently the diagnosis of a case of neuroschistosomiasis in the environs of Juiz de Fora awoke the need for updated investigations of the intermediate hosts of S. mansoni and on the possibility that these are infected.

So, this work focuses on the geographic distribution of Biomphalaria in Juiz de Fora municipality with identification of the species found, possibility of infectivity, and main types of related habitats. This updated study of the occurrence of intermediate hosts in the region confirms, for the first time, the presence of $B$. straminea in the municipality, with the study of this snail susceptibility of the Juiz de Fora strain to S. mansoni.

\section{MATERIALS AND METHODS}

Location under study - This study was carried out in the municipality of Juiz de Fora (21S14/42W14), in the mesoregion known as the Zona da Mata Mineira, Minas Gerais, Brazil (Fig. 1). This municipality is located $280 \mathrm{~km}$ from Belo Horizonte, the state capital, and $184 \mathrm{~km}$ from the city of Rio de Janeiro. Juiz de Fora has a land area of $1,429.875 \mathrm{~km}^{2}$, with a population of 419,226 inhabitants according to the 2000 census. The municipality, with an average altitude of $800 \mathrm{~m}$, has an ample hydrographic basin rich in lakes, ponds, and irrigation ditches. The spatial localization of the foci was determined by instant positioning from a GPS (Global Positioning System) apparatus.

Malacological survey - These surveys were performed in collaboration with technicians from DADS/Juiz de Fora (Directorate for Decentralized Health Actions, an organ of the State Health Secretariat). The specimens were collected from lotic and lentic ecosystems in the municipality, predominantly around the urban perimeter, where the characteristics are favorable to the occurrence and spa- tial dispersion of snails near human populations. We captured the specimens with the aid of tongs and nets. The study was conducted in 2003 to 2004 .

Snails - After collection, the snails were taken to the laboratory where the living specimens were measured. After examination under artificial light for $S$. mansoni cercarie, the snails were submitted to squeezing between glass plates to detect the presence of cercariae. Some specimens were separated for morphological identification (Paraense 1975). Another sample of specimens was packed and sent to the René-Rachou Research Center for molecular identification (Vidigal et al. 1998) and to obtain descendents (F1) for susceptibility assays.

Susceptibility of B. straminea - One hundred specimens $\mathrm{F} 1$ of $B$. straminea were exposed to 50 miracidia of $S$. mansoni (strain LE). For infection control, 50 specimens of B. glabrata, reared under laboratory conditions (Belo Horizonte/MG), with 8-10 mm diameter, were exposed to $10 \mathrm{miracidia} / \mathrm{snail}$. After a 30 -days exposition, the snails were individually placed under artificial light and examined by stereomicroscopy. These snails were evaluated weekly until 60 days after infection. The negative specimens were examined and submitted to squeezing between glass slides.

\section{RESULTS}

Malacological survey - The study concentrated on 31 lotic sites (ditches, waterfalls) and lentic sites (rudimentary ponds, reservoirs, ornamental ponds) distributed in the eight geographical regions of the municipality of Juiz de Fora (located in the Minas Gerais - Zona da Mata). We collected a total of 5264 specimens of Biomphalaria and identified them morphologically by analysis of the shell, reproductive and renal system (Paraense 1975), and by polymerase chain reaction (PCR) (Vidigal et al. 1998).

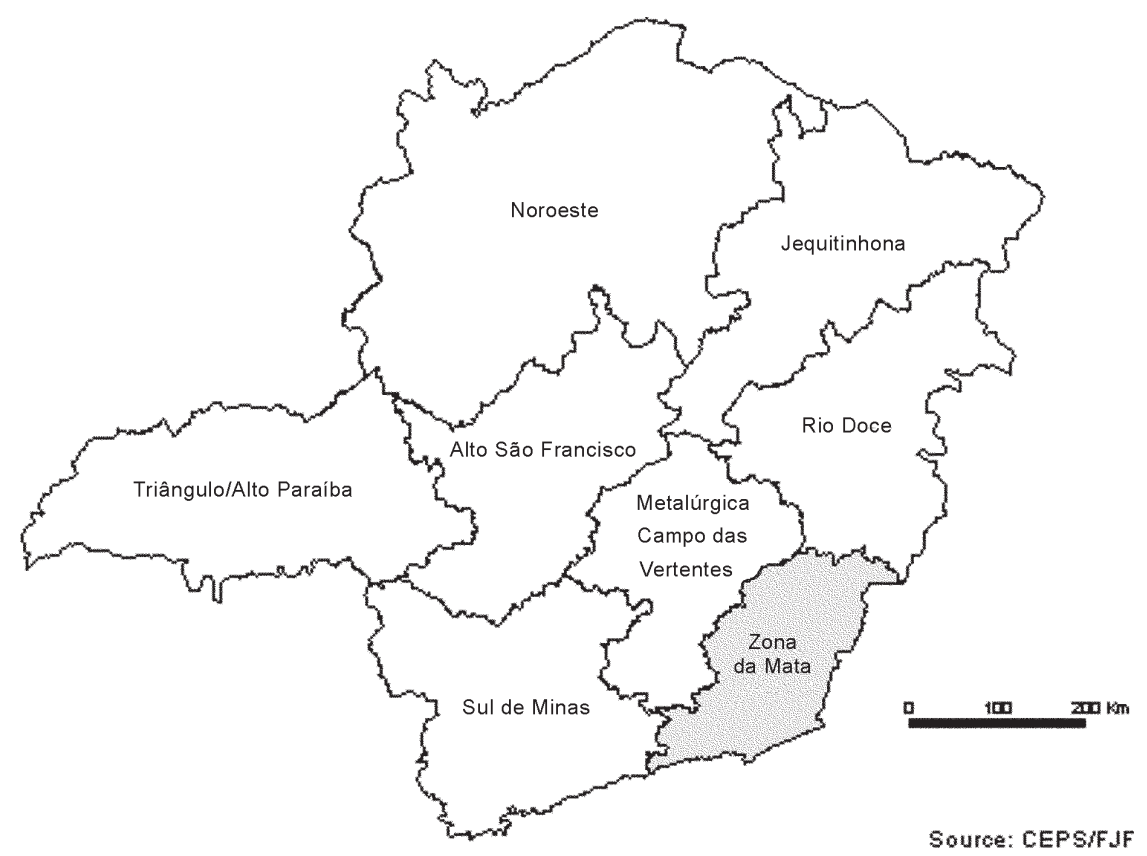

Fig. 1: map of mesoregions of the state of Minas Gerais, Brazil in 1996. 
The Table shows the sites studied, their geographic position and the species found. As can be seen, of the 31 sites studied, 6 were reservoirs, 11 rudimentary holding ponds, 7 truck farms with irrigation ditches, 5 lakes, 1 ornamental pond, and 1 waterfall. We found no species of Biomphalaria in the reservoirs, lakes, and waterfall studied. However, we found three different species of Biomphalaria in $100 \%$ of the irrigation ditches studied: $B$. tenagophila, B. Peregrina, and B. straminea. Of the 11 rudimentary ponds studied, we found the species $B$. tenagophila in $27 \%$.

The Fig. 2 shows that of the 31 sites studied, B. tenagophila was the species most commonly found, accounting for $60 \%$ of the positive points. B. peregrina was found at $20 \%$ of the points, all outside the urban perimeter. $B$ straminea was found at $20 \%$ of the points in irrigation ditches. This is the first report of this species in the municipality.

Infection of the snails by S. mansoni - We did not find any infections by $S$. mansoni in the 5264 specimens collected, which were evaluated both by the technique of exposure to artificial light and squeezing.

Susceptibility to B. straminea - We subjected the snails collected at the coordinates $21^{\circ} 39^{\prime} 59^{\prime \prime}$ 'S, $43^{\circ} 25^{\prime} 09^{\prime \prime} \mathrm{W}, 716$ $\mathrm{m}$ of altitude, to the test for susceptibility to $S$. mansoni and the Juiz de Fora strain of B. straminea, finding $25.4 \%$ infectivity, in contrast to the Belo Horizonte strain, which showed $91.6 \%$ infectivity.

TABLE

List of sites, geographic position determined by GPS and Biomphalaria species studied, predominantly around the urban perimeter of Juiz de Fora, Minas Gerais, Brazil

\begin{tabular}{|c|c|c|c|c|}
\hline Collection site & $\begin{array}{l}\text { Type of } \\
\text { collection site }\end{array}$ & Coordinates & Region & $\begin{array}{l}\text { Species of } \\
\text { Biomphalaria }\end{array}$ \\
\hline João Penido (Remonta) & Reservoir & $21^{\circ} 40^{\prime} 47^{\prime \prime S} 43^{\circ} 23^{\prime} 43^{\prime \prime} \mathrm{W}$ & North & Negative \\
\hline Chapéu D’Uvas & Reservoir & $21^{\circ} 34^{\prime} 57^{\prime \prime S} 43^{\circ} 33^{\prime} 10^{\prime \prime} \mathrm{W}$ & North & Negative \\
\hline João Penido (Náutico) & Reservoir & $21^{\circ} 38^{\prime} 37^{\prime \prime S} 43^{\circ} 23^{\prime} 41^{\prime \prime} \mathrm{W}$ & North & Negative \\
\hline Poço D’Anta (Cesama ) & Reservoir & $21^{\circ} 44^{\prime} 31^{\prime \prime S} 43^{\circ} 24^{\prime} 05^{\prime \prime} \mathrm{W}$ & East & Negative \\
\hline Sobragi & Reservoir & $21^{\circ} 58^{\prime} 44^{\prime \prime S} 43^{\circ} 22^{\prime} 07^{\prime \prime} \mathrm{W}$ & South & Negative \\
\hline São Pedro & Reservoir & $21^{\circ} 39^{\prime} 59^{\prime \prime} \mathrm{S} 43^{\circ} 25^{\prime} 09^{\prime \prime} \mathrm{W}$ & West & Negative \\
\hline Barreira do Triunfo & Irrigation ditch & $21^{\circ} 39^{\prime} 59^{\prime \prime} \mathrm{S} 43^{\circ} 25^{\prime} 09^{\prime \prime} \mathrm{W}$ & North-West & B. straminea \\
\hline Milho Branco & Irrigation ditch & $21^{\circ} 44^{\prime} 31^{\prime \prime S} 43^{\circ} 24^{\prime} 25^{\prime \prime} \mathrm{W}$ & North-West & B. straminea \\
\hline Bandeirantes & Irrigation ditch & $21^{\circ} 43^{\prime} 25^{\prime \prime} \mathrm{S} 43^{\circ} 21^{\prime} 20^{\prime \prime} \mathrm{W}$ & North-East & B. tenagophila \\
\hline Vivendas da Serra & Irrigation ditch & $21^{\circ} 43^{\prime} 03^{\prime \prime S} 43^{\circ} 20^{\prime} 56^{\prime \prime} \mathrm{W}$ & North-East & B. tenagophila \\
\hline Córrego Yung & Irrigation ditch & $21^{\circ} 41^{\prime} 20^{\prime \prime S} 43^{\circ} 18^{\prime} 27^{\prime \prime} \mathrm{W}$ & East & B. tenagophila \\
\hline Granjeamento Dias Tavares & Irrigation ditch & $21^{\circ} 38^{\prime} 51^{\prime \prime S} 43^{\circ} 28^{\prime} 39^{\prime \prime} \mathrm{W}$ & North & B. peregrina \\
\hline Grama-Ribeirão das Rosas & Irrigation ditch & $21^{\circ} 41^{\prime} 23^{\prime \prime S} 43^{\circ} 20^{\prime} 30^{\prime \prime} \mathrm{W}$ & North-East & B. tenagophila \\
\hline Granjeamento Dias Tavares & Rudimentary pond & $21^{\circ} 38^{\prime} 46^{\prime \prime S} 43^{\circ} 29^{\prime} 35^{\prime \prime} \mathrm{W}$ & North & B. tenagophila \\
\hline \multicolumn{5}{|l|}{ Army Training Camp/ } \\
\hline Barbosa Lage & Rudimentary pond & $21^{\circ} 42^{\prime} 09^{\prime \prime S} 43^{\circ} 22^{\prime} 54^{\prime \prime} \mathrm{W}$ & North & Negative \\
\hline \multicolumn{5}{|l|}{ Vale do Oeste Paid Fishing Park/ } \\
\hline Highway BR 040 & Rudimentary pond & $21^{\circ} 45^{\prime} 27^{\prime \prime S} 43^{\circ} 26^{\prime} 37^{\prime \prime} \mathrm{W}$ & North & Negative \\
\hline Humaitá (Sítio Recanto do Sol) & Rudimentary pond & $21^{\circ} 44^{\prime} 26^{\prime \prime} \mathrm{S} 43^{\circ} 30^{\prime} 01^{\prime \prime} \mathrm{W}$ & North & Negative \\
\hline \multicolumn{5}{|l|}{ Humaitá } \\
\hline (Sítio Recanto do Sol Highway) & Rudimentary pond & $21^{\circ} 44^{\prime} 26^{\prime \prime S} 43^{\circ} 20^{\prime} 01^{\prime \prime} \mathrm{W}$ & North & Negative \\
\hline Yung & Rudimentary pond & $21^{\circ} 42^{\prime} 21^{\prime \prime S} 43^{\circ} 18^{\prime} 27^{\prime \prime} \mathrm{W}$ & East & B. tenagophila \\
\hline Vivendas da Serra & Rudimentary pond & $21^{\circ} 43^{\prime} 06^{\prime \prime S} 43^{\circ} 20^{\prime} 51^{\prime \prime} \mathrm{W}$ & North-East & Negative \\
\hline Hotel Fazenda São Fidelis & Rudimentary pond & $21^{\circ} 44^{\prime} 45^{\prime \prime S} 43^{\circ} 14^{\prime} 48^{\prime \prime} \mathrm{W}$ & South-East & Negative \\
\hline Santana Farm (Sarandira Highway) & Rudimentary pond & $21^{\circ} 48^{\prime} 04^{\prime \prime S} 43^{\circ} 10^{\prime} 55^{\prime \prime} \mathrm{W}$ & South-East & Negative \\
\hline \multicolumn{5}{|l|}{ Rest.Recanto das Garças/ } \\
\hline Highway BR 040 & Rudimentary pond & $21^{\circ} 52^{\prime} 04^{\prime \prime S} 43^{\circ} 21^{\prime} 01^{\prime \prime} \mathrm{W}$ & South & B. peregrina \\
\hline Trevo de Torreões & Rudimentary pond & $21^{\circ} 39^{\prime} 599^{\prime \prime S} 43^{\circ} 25^{\prime} 03^{\prime \prime} \mathrm{W}$ & North & Negative \\
\hline Mariano Procópio Museum & Lake & $21^{\circ} 44^{\prime} 78^{\prime \prime} \mathrm{S} 43^{\circ} 21^{\prime} 65^{\prime \prime} \mathrm{W}$ & Center & Negative \\
\hline Lake Manacás/ UFJF & Lake & $21^{\circ} 46^{\prime} 68^{\prime \prime S} 43^{\circ} 22^{\prime} 22^{\prime \prime} \mathrm{W}$ & West & Negative \\
\hline ASE & Lake & $21^{\circ} 42^{\prime} 51^{\prime \prime S} 43^{\circ} 23^{\prime} 27^{\prime \prime W}$ & North-West & Negative \\
\hline SESC & Lake & $21^{\circ} 47^{\prime} 26^{\prime \prime S} 43^{\circ} 23^{\prime} 57^{\prime \prime} \mathrm{W}$ & West & Negative \\
\hline Lajinha Park & Lake & $21^{\circ} 47^{\prime} 56^{\prime \prime S} 43^{\circ} 21^{\prime} 98^{\prime \prime} \mathrm{W}$ & South & Negative \\
\hline Halfeld Park & Ornamental pond & $21^{\circ} 45^{\prime} 72^{\prime \prime S} 43^{\circ} 21^{\prime} 05^{\prime \prime} \mathrm{W}$ & Center & Negative \\
\hline Vale do Ipê & Waterfall & $21^{\circ} 45^{\prime} 26^{\prime \prime} \mathrm{S} 43^{\circ} 21^{\prime} 96^{\prime \prime} \mathrm{W}$ & Center & Negative \\
\hline
\end{tabular}

$a$ : the sites in table and map were classified using the following definition of terms: Rudimentary pond, a rustic construction to hold water; Reservoir, a reservoir behind a professionally engineered dam or dike; Lake, a large extension of water surrounded by land, normally of pluvial origin (natural or artificial); Ornamental pond, a small extension of water or small lake for ornamental purposes; Waterfall, a vertical fall of water; Irrigation ditch, small collections of water for crop irrigation. 


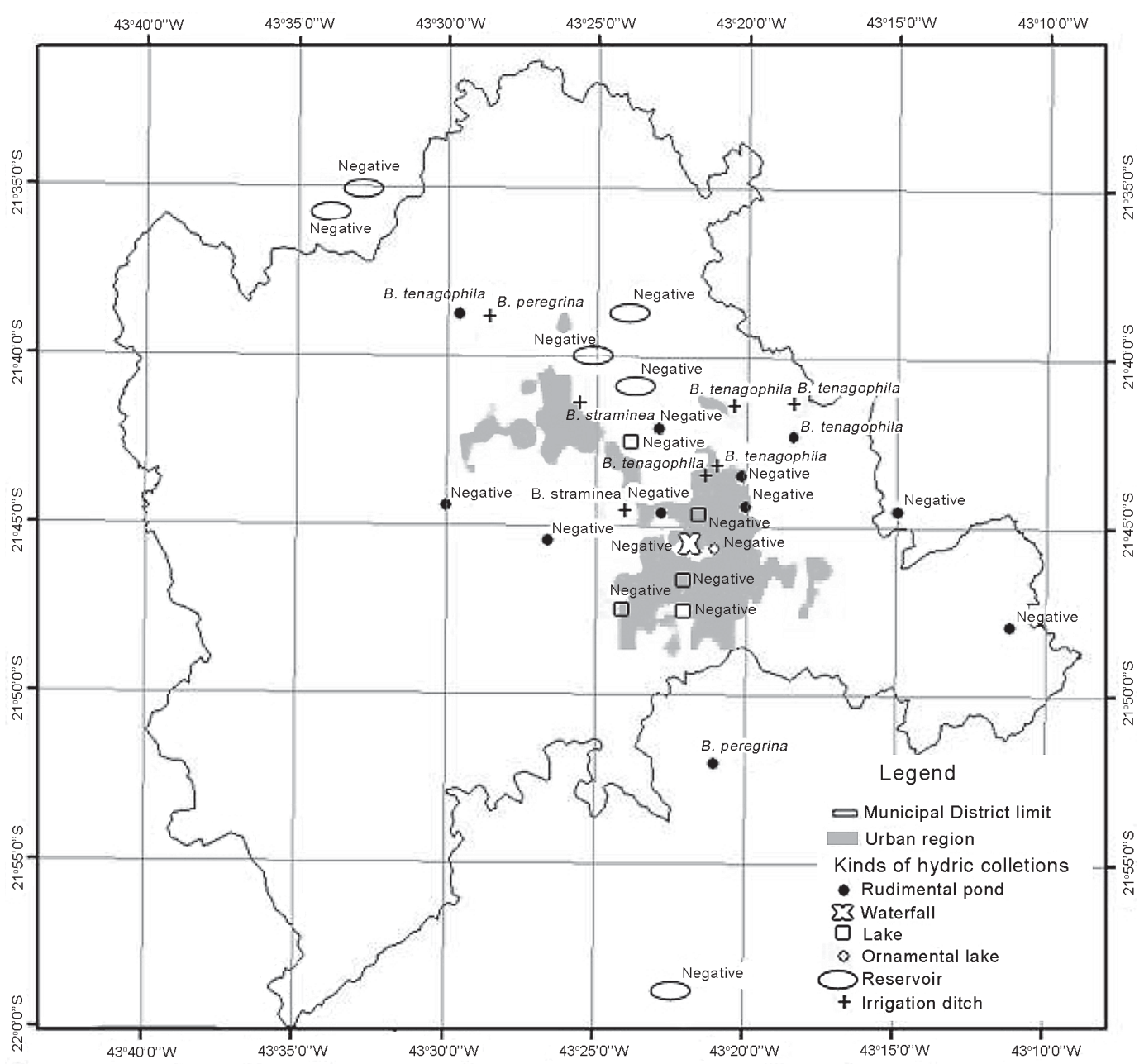

Fig. 2: map showing the distribution of the Biomphalaria species found in the municipality of Juiz de Fora, Minas Gerais, Brazil.

\section{DISCUSSION}

This is the first geographic mapping study, through GPS, involving snail hosts of $S$. mansoni in the municipality of Juiz de Fora, the main socioeconomic center in the Zona da Mata Mineira of the state of Minas Gerais. Upto-date information on the occurrence of Biomphalaria in this region is rare. This work helps to improve knowledge of the local reality and provides support for the planorbids mapping of the state. Minas Gerais has a land area of 5,384,000 $\mathrm{km}^{2}$, making it Brazil's fourth largest by geographic area. It has areas where schistosomiasis is highly endemic, a large number of water bodies and courses, and is a magnet for ecotourism. It is divided into 12 political-administrative mesoregions, among them the Zona da Mata Mineira, with 2 million inhabitants and a low municipal human development index (IDH-M). Approximately $90 \%$ of its 144 municipalities have no record in the literature on the prevalence of Biomphalaria sp.

Pinto and Deslandes (1953) and Paraense and Deslandes (1956) verified the occurrence of B. glabrata, $B$. tenagophila, and B. peregrina in Juiz de Fora municipality. As can be observed in this work (Table and Figure), we reaffirmed the presence of $B$. tenagophila and $B$. peregrina, and identified $B$. straminea for the first time in the municipality, but we did not find B. glabrata, as reported by the previous authors. B. glabrata is from an epidemiological standpoint considered to be the most important host species in the Americas, due to the high biological potential of natural infection and its wide distribution. Souza et al. (2001) in a survey of planorbidae in Zona da Mata Mineira, reported finding B. glabrata in $100 \%$ followed by $B$. tenagophila in $40 \%$, and B. straminea in $20 \%$ of the 15 municipalities studied. The fact we did not find B. glabrata again in the municipality of Juiz de Fora can be evaluated due to changes in a great number of biotic or abiotic factors, such as climate, water chemistry, predation, parasitism, competition, and anthropogenic perturbations. Therefore, the initial report of $B$. glabrata in Juiz de Fora, a half century ago, was due to the fact that the urban perimeters were not well defined at that time and could have been confused with the rural limits of neighboring municipalities, particularly Tabuleiro and Piau, recognized as habitats of B. glabrata (Souza et al. 2001). Another hypothesis involves the competitive superiority of $B$. straminea, observed in data on the population interactions of B. glabrata and B. straminea, where the first 
specie has been replaced by the latter (Michelson \& Dubois 1979). The lesser susceptibility of $B$. straminea to $S$. mansoni could justify action for control by substitution of one species by another. In Martinique, B. glabrata is mentioned as a rare species because of its possible natural substitution by B. straminea (Guyard \& Pointer 1979). The inverse phenomenon appears to be occurring in the state of Pará, with the appearance of B. glabrata in places supposedly occupied only by $B$. straminea $(\mathrm{Pa}-$ raense 1986).

Such superiority might be based on some characteristics found in B. straminea, such as greater resistance to desiccation and to infestation by S. mansoni; greater vagility and capacity to disperse; or its greater fertility in relation to B. glabrata. One of the most characteristic traits of the snail-digenetic interaction is its specificity, and the fact that B. glabrata has not been found again to date explains, from the standpoint of specificity, why $S$. mansoni was not found in the municipality, even though $B$. straminea is an important host in the Brazil's Northeast Region. This Schistosoma-B. glabrata compatibility is a direct consequence of the complex relations between snail and host and can be considered as an amalgamation of physiological and behavioral interactions. Both the snail's susceptibility and the parasite's infectivity contribute to this highly specific relationship and are genetically defined.

The occurrence of B. straminea in the municipality was reported for the first time in this work, although statewide it is more amply distributed when compared to $B$. tenagophila. In Zona da Mata, $B$. straminea had already been reported in the municipalities of Ponte Nova, Ubá, and Rio Casca (Souza et al. 2001). Although B. straminea constitutes an intermediate host experimentally taken as less apt to transmit S. mansoni, due to the lower specificity of the parasite-host relationship, strains from outback and coastal zones in Brazil's Northeast Region are responsible for maintaining the high endemic prevalence in that region (Teles 1996). In Minas Gerais, the B. straminea specimens studied in the majority of reports have not shown infection, even though this species was pointed to as responsible for an outbreak of schistosomiasis in Paracatu municipality (Carvalho et al. 1987).

In this manner, the $B$. straminea strain found in Juiz de Fora, tested for susceptibility to $S$. mansoni, showed $25.4 \%$ infectivity in relation to the Belo Horizonte control strain. This index can be considered high when compared with the susceptibility data for the species cited in the literature (Gerken et al. 1975, Souza et al. 1981a, b, 1983, Souza 1986, Fernandez \& Thiengo 2002, Massara et al. 2002).

The irrigation ditches studied here are used by truck farmers in the so-called green belt of Juiz de Fora. They are mainly smallholders who market their crops directly. Although planorbidae of the genus Biomphalaria can be found in various freshwater habitats, both natural and artificial, except for very deep water bodies or fast-flowing watercourses, their population density tends to be greater in artificial breeding grounds such as drainage and irrigation ditches or small collection ponds (Cunha 1970). This corroborates the fact that all the truck farms investigated in Juiz de Fora municipality were positive for Biomphalaria. One of them, located on the urban perimeter (coordinates: S $21^{\circ} 41^{\prime} 23^{\prime \prime}$ and W 43 $20^{\prime} 30^{\prime \prime}$ ) and colonized by $B$. tenagophila, is only $15 \mathrm{~km}$ from a focus of contamination within the rural limits. This evidence, associated with the large migratory movement in the microregion, the poor basic sanitation conditions and low sanitary education of the local people, form ingredients that could well lead to propagation of schistosomiasis in the urban area of Juiz de Fora municipality and its mesoregion.

Having met the objectives of systematic updating, identification and evaluation of the infectivity and susceptibility of host snails of $S$. mansoni in the municipality, the data obtained are now being used in broader efforts to help control the disease in Zona da Mata Mineira. Through a partnership between the academic community of University Federal of Juiz de Fora and the technical staff of the Directorate for Decentralized Health Actions of the State Health Secretariat (DADS/JF), the study has been expanded to the neighboring municipalities (microregion), and at the same time an Extension Project is being established to seek operational solutions with the Brazilian National Health System (SUS, Sistema Único de Saúde), to prevent the spread of this endemic disease in the region.

\section{ACKNOWLEDGEMENTS}

To Ricardo José de Paula Souza e Guimarães, Instituto Nacional de Pesquisas Espaciais, for help us with the spatial reference.

\section{REFERENCES}

Campbell G, Jones CS, Lockyer A E, Hughes S, Brown D, Noble LR, Rollinson D 2000. Molecular evidence supports an African affinity of the Neotropical freshwater gastropod, Biomphalaria glabrata, Say 1818, an intermediate host for Schistosoma mansoni. Proc Royal Society London B 267: 2351-2358.

Carvalho OS, Massara CL, Silveira Neto HV, Guerra HL, Caldeira RL, Mendonça LF, Vidigal THDA, Chaves A, Katz N 1997. Re-evalution of schistosomiasis mansoni in Minas Gerais, Brazil. II Alto Paranaíba mesoregion. Mem Inst Oswaldo Cruz 92: 141-142.

Carvalho OS, Rocha RS, Massara CL, Katz N 1987. Expansão da esquistossomose mansoni em Minas Gerais. Mem Inst Oswaldo Cruz 88: 295-298.

Cunha AS 1970. Epidemiologia. In Esquistossomose Mansônica, Sarvier, São Paulo, p. 31.

DeJong RJ, Morgan JAT, Paraense WL, Pointier JP, Amarista M, Ayeh-Kumi PFK, Babiker A, Barbosa CS, Brémond P, Canese AP, Souza CP, Dominguez C, File S, Gutierrez A, Incani RN, Kawano T, Kazibwe F, Kpikpi J, Lwambo NJS, Mimpfoundi R, Njiokou F, Poda JN, Sene M, Velásquez LE, Yong M, Adema CM, Hofkin BV, Mkoji GM, Loker ES 2001. Evolutionary relationships and biogeography of Biomphalaria (Gastropoda: Planorbidae) with implications regarding its role as host of the human bloodfluke, Schistosoma mansoni. Mol Biol Evolution 18: 2225-2239.

Fernandez MA, Thiengo SC 2002. Susceptibility of Biom- 
phalaria straminea da Mesa Dam, Goiás, Brazil to infection with three strains of Schistosoma mansoni Sambon, 1907. Mem Inst Oswaldo Cruz 97: 59-60.

Gerken SE, Araújo MPT, Freitas JR 1975. Suscetibilidade de Biomphalaria straminea da região de Lagoa Santa (MG) ao Schistosoma mansoni. Rev Inst Med Trop São Paulo 17: 338-343.

Guyard A, Pointer JP 1979. Faune malacologique dulçaquicole et vecteurs de la schistosome intestinale en Martinique. Ann Parasit Paris 2: 193-205.

Lockyer AE, Jones CS, Noble LR, Rollinson D 2004.Trematodes and snails: an intimate association. Can J Zool 82: 251-269.

Massara CL, Carvalho OS, Caldeira RL, Janonotti-Passos LK, Schall VT 2002. First report on the presence of Biomphalaria straminea in the municipality of Jaboticatubas, state of Minas Gerais, Brazil. Mem Inst Oswaldo Cruz 97: 27-29.

Michelson EH, Dubois L 1979. Competitive interaction between two snail hosts of Schistosoma mansoni: laboratory studies on Biomphalaria glabrata and B. straminea. Rev Inst Med Trop São Paulo 21: 246-253.

Paraense WL 1975. Estado atual da sistemática dos planorbídeos brasileiros. Arq Museu Nacional Rio de Janeiro 55: 105128.

Paraense WL 1986. A xistosomose mansoni no Pará. In Instituto Evandro Chagas: 50 Anos de Contribuição às Ciências Biológicas e à Medicina Tropical, Fundação Serviços de Saúde Pública, Belém, v. 1, p. 207-219.

Paraense WL, Deslandes N 1956. Observations on Australorbis janeirensis (Clessin, 1884). Rev Bras Biol 16: 81-102.

Schall V, Diniz MCP 2001. Information and education in schistosomiasis control: an analysis of the situation in the state of Minas Gerais, Brazil. Mem Inst Oswaldo Cruz 96: 35-43.

Souza CP 1986. Estudo de moluscos do gênero Biomphalaria de Minas Gerais, com relação à adaptação parasitohospedeiro e a importância na epidemiologia da esquistossomose. Rev Inst Med Trop São Paulo 28: 287-292.

Souza CP, Araújo N, Azevedo MLL 1983. Estudo da potencialidade de populações de Biomphalaria straminea de Minas Gerais, como hospedeiras do Schistosoma mansoni. Mem Inst Oswaldo Cruz 78: 251-256.

Souza CP, Caldeira RL, Drummond SC, Melo AL, Guimarães CT, Soares DM, Carvalho OS 2001. Geographical distribution of Biomphalaria snails in the state of Minas Gerais, Brazil. Mem Inst Oswaldo Cruz 96: 293-302.

Souza CP, Rodrigues MS, Araújo N 1981a. Suscetibilidade de Biomphalaria straminea (Dunker, 1848), de Belo Horizonte (MG) à infecção por cepas de Schistosoma mansoni. Rev Inst Med Trop São Paulo 23: 188-193.

Souza CP, Rodrigues MS, Azevedo MLL, Araújo N 1981b. Suscetibilidade de populações de Biomphalaria straminea (Dunker, 1848) de Minas Gerais. Rev Inst Med Trop São Paulo 23: 212-216.

Teles HMS 1996. Distribuição de Biomphalaria straminea ao sul da região Neotropical, Brasil. Rev Saúde Pública 30: 341-349.

Vidigal THDA, Spatz L, Nunes DN, Simpson AJG, Carvalho OS, Dias Neto E 1998. Biomphalaria spp. Identification of the intermediate snails hosts of Schistosoma mansoni by polymerase chain reaction amplification and restriction enzyme digestion of the ribosomal RNA gene intergenic spacer. Exp Parasitol 89: 180-187.

WHO-World Health Organization 1998. The control of schistosomiasis. Technical Report Series no. 728. 